\title{
UNDERSTANDING ENTREPRENEURIAL INTENTIONS AROUND THE WORLD: AN EMPIRICAL APPROACH
}

\section{COMPREENDENDO AS INTENÇÕES EMPREENDEDORAS NO MUNDO: UMA ABORDAGEM} EMPÍRICA

Recebido em 14.12.2019 Aprovado em 09.03.2020

Avaliado pelo sistema double blind review

\section{Ricardo Gouveia Rodrigues}

DOI: https://doi.org/10.32888/cge.v8i1.39903

\author{
rgrodrigues@ubi.pt \\ NECE-UBI (R\&D Centre funded by the Multiannual Funding Programme of R\&D Centres of FCT - Portuguese \\ Foundation for Science and Technology, Ministry of Education and Science), Faculty of Social and Human Sciences, \\ University Beira Interior, Estrada do Sineiro, s/n, 6200-209 Covilhã, Portugal. \\ https://orcid.org/0000-0001-6382-5147
}

\section{Isabel Cristina Panzeira Marques}

marquesenf25@gmail.com

Department of Business and Economics, Faculty of Social and Human Sciences, University Beira Interior, Estrada do Sineiro, s/n, 6200-209 Covilhã, Portugal.

https://orcid.org/0000-0002-3407-2673

\section{Susana Geraldes}

susanageraldes@gmail.com

Department of Business and Economics, Faculty of Social and Human Sciences, University Beira Interior, Estrada do Sineiro, s/n, 6200-209 Covilhã, Portugal.

https://orcid.org/0000-0002-6581-3454

\begin{abstract}
Entrepreneurship tends to add value to products and services, enables the creation of new jobs, enhances productivity and consequently economic development. The objective of this paper is to study the phenomenon of entrepreneurship through understanding of the effect of several variables in Entrepreneurial Intensions. Based on variables extracted from Global Entrepreneurship Monitor databases and in order to analyze the association between the variables, the Pearson Correlation was performed, followed by a Multiple Linear Regression model to list which variables explain the entrepreneurial intentions in a significant way. The results of correlations show significant positive correlation between Perceived Capabilities, Entrepreneurship as a Good Career Choice, High Status to Successful Entrepreneurs and Total Early-Stage Entrepreneurial Activity and Entrepreneurial Intentions. The significant predictors found for Entrepreneurial Intentions were the Perceived Capabilities, Entrepreneurial Activity in the Initial Phase, High Status for Successful Entrepreneurs, and Motivation. Variables concerning behavior and attitudes are the best explanatory for entrepreneurial intentions in the world; none of the variables considering framework conditions entered in the model.
\end{abstract}

Keywords: Entrepreneurial Intentions. GEM. Behaviour and Attitudes. Framework Conditions.

\section{Resumo}

O empreendedorismo tende a contribuir com valor para produtos e serviços, possibilita a criação de novos empregos, aumenta a produtividade e, consequentemente, o desenvolvimento econômico. O objetivo deste artigo é estudar o fenômeno do empreendedorismo através da compreensão do efeito de várias variáveis nas Intenções Empreendedoras. Com base nas variáveis extraídas dos bancos de dados do Global Entrepreneurship Monitor e para analisar a associação entre as variáveis, foi realizada a Correlação de Pearson, seguida de um modelo de Regressão Linear Múltipla para listar quais variáveis explicam as intenções empreendedoras de maneira significativa. Os resultados das correlações mostram correlação positiva significativa entre Capacidades Percebidas, Empreendedorismo como uma Boa Escolha de Carreira, Alto Status para Empreendedores de Sucesso e Atividade Empreendedora Total em Estágio Inicial e Intenções Empreendedoras. Os preditores significativos encontrados para as Intenções Empresariais foram: Capacidades Percebidas, Atividade Empreendedora na Fase Inicial, Alto Status para Empreendedores de Sucesso e Motivação. Variáveis sobre comportamento e atitudes são as melhores explicações para intenções empresariais no mundo; nenhuma das variáveis considerando as condições da estrutura foram inseridas no modelo.

Palavras-chave: Intenções empreendedoras. GEM. Comportamento e atitudes. Condições de estrutura. 


\section{Introduction}

Entrepreneurship is considered a significant and important factor for the economic development of a country and for new job creation and innovation (Mirjana et al., 2018; Ros et al., 2017; Rusu and Roman, 2018). Given the positive effects of entrepreneurship on a country's economy, the promotion of entrepreneurship is a national priority for many governments around the world (Karimi et al., 2015; Rusu and Roman, 2018).

According Mirjana et al. (2018) and Esfandiar et al. (2019), entrepreneurship is an innovative and creative process where there is potential to add value to products, create job opportunities, raise productivity, revitalize and diversify markets, improve social welfare, and more broadly to develop the economy.

Entrepreneurship begins when an individual decides to undertake a new venture. Consequently, it is necessary to understand just how people reach the decision to do it (Karimi et al., 2015). Understanding and examining the factors which affect the decision of individuals to become entrepreneurs play a significant role for the decision makers in order to identify the adequate measures that can support and develop the entrepreneurial activity (Rusu and Roman, 2018).

Mirjana et al. (2018), defended that entrepreneurship is determined by different economic and non-economic conditions and it is possible to distinguish three sets of factors: personal characteristics of an individual including its socio-demographics and personality traits; economic environment, including macroeconomic variables, industrial and financial market conditions; and functioning of institutions and sociological variables, including formal institutions, the role of cultural values and social. Robichaud et al. (2010) have highlighted that entrepreneurial motivations can be intrinsic and extrinsic: starting from the desire of individuals to increase their independence and up to financial motivations, and some factors related to family but also work-related factors. Smith-Hunter et al. (2003) considered Entrepreneurship as the result of the interaction between internal and external factors. Passaro et al. (2017), referred that scholars in entrepreneurship to analysed people's pre-selfemployment decisions should consider factors related to either individual (subjective traits, demographics, etc.) or contextual variables (such as social and cultural characters or financial facilitations).

So, it is important to know how early-stage potential entrepreneurs' intentions originate as well as what factors stimulate entrepreneurship. To comprehend people propensity towards the entrepreneurial choice schoolers focuses on the study of Entrepreneurial Intentions (EI) (Esfandiar et al., 2019; Passaro et al., 2017) and recent research notes the importance of intention-based models as they include a theory-based and process-oriented perspective to explain precursors of EI (Al-Jubari et al., 2018; Crespo et al., 2018; Fernandes et al., 2018; Mirjana et al., 2018; Passaro et al., 2017; Potishuk and Kratzer, 2017; Rodriguez et al., 2017). Understand the consequences of intentions require that we understand the antecedents of intention. Much of entrepreneurship is intentional, and, therefore, the use of intention models should provide a good means of examining the precursors to business start-up (Krueger et al., 2000).

Based on above arguments, the objective of this paper is to study the phenomenon of entrepreneurship through understanding of the effect of several variables in EI. We intend to develop a model that considers at the same time different types of variables (intrinsic and extrinsic, internal and external) in order to elucidate the EI in the world. Examination of entrepreneurial intentions across different nations and cultures it's an important issue because normally researches focuses only on a single culture, region, country or continent. Thus, we used two databases from Global Entrepreneurship Monitor (GEM) data that is available to the year 2017.

The results of the analyses of correlations show that "Perceived Capabilities", "Entrepreneurship as a Good Career Choice", "High Status to Successful Entrepreneurs" and "Total Early-Stage Entrepreneurial Activity" positively and significantly influence "Entrepreneurial Intentions". The linear regression model shows that the variables that best predict "Entrepreneurial Intentions" are "Perceived Capabilities", "Total Early-Stage Entrepreneurial Activity", "High Status to Successful Entrepreneurs" and "Motivation". The reminder of this article is organized as follows: second section outlines the theoretical background, related to EI. Third section contains a description of the data set, method, and variables. In fourth section we detail the results, and in fifth section, we conclude with a summary of the main findings.

ISSN 2318-9231

CGE | Rio de Janeiro | v. 8 | n. 1 | jan. - abr. 20202 


\section{Literature Review}

According Bae et al., (2014), EI are desires to own or start a business. Moriano et al. (2011) defined EI as "the conscious state of mind that precedes action and directs attention toward entrepreneurial behaviours such as starting a new business and becoming an entrepreneur" (p. 165). Entrepreneurial Intention can be realized as the initial action in the entrepreneurial process (Bae et al., 2014; Khalifa and Dhiaf, 2016; Krueger et al., 2000).

Historically, intentions have been used to describe a self-prediction to employ a certain behaviour (Ajzen, 1991). That is, once the formation of intentions occurs, actual behaviour is expected. Social-psychological studies assume that intention is the single best predictor of actual behaviour (Bae et al., 2014). Intention models, indirectly influenced by individual factors, offers a way to understand the direct precursors to business start-ups and predict consequences of intentions in that they capture longer term tendencies held by individuals (Esfandiar et al., 2019). These models offer a richer understanding of intentions because they consider at the same time personal and situational factors (Krueger et al., 2000)

There have been a number of competing models of behavioural intentions in the literature identifying a somewhat similar set of constructs. Two of these frameworks are the Shapero's model of the Entrepreneurial Event (SEE) (Shapero and Sokol, 1982) and Theory of Planned Behaviour (TPB) (Ajzen, 1991). As pointed out by Fernandes et al. (2018) and Esfandiar et al. (2019), these models have been central to entrepreneurship research, yet there exists a relatively unexplored alternative approach to integrate the two models and introduce a new, more developed and systematic model into the entrepreneurship literature.

According to SEE, the decision to initiate a new entrepreneurial activity depends on three elements: the perception of desirability, feasibility and the individual's willingness to act (Esfandiar et al., 2019; Krueger et al., 2000; Rodrigues et al., 2017; Shapero and Sokol, 1982). Shapero and Sokol (1982) defined perceived desirability as the personal attractiveness of starting a business, including both intrapersonal and extra personal impacts; Perceived feasibility as the degree to which one feels personally capable of starting a business and conceptualized "propensity to act" as the personal disposition to act on one's decisions, thus reflecting volitional aspects of intentions.

The TPB has been widely operationalized and examined in the entrepreneurship literature (Al-Jubari et al., 2018; Fernandes et al., 2018; Mirjana et al., 2018; Passaro et al., 2017; Potishuk and Kratzer, 2017; Rodriguez et al., 2017) and it was grounded on the premise that three determinants: attitude toward outcomes of the behaviour, social/subjective norms and perceived behavioural control, directly provide the motivational basis for intention to perform the behaviour (Esfandiar et al., 2019). The first one refers to the degree to which an individual has a favourable or unfavourable appraisal of the behaviour in question. Social/subjective norms refer to the extent to which an individual perceives his or her behaviour is consistent with significant others' thoughts. Perceived behavioural control is the extent to which the target behaviour is within a decision maker's ability (Ajzen, 1991).

Both models are largely inseparable because both have an element conceptually associated with perceived selfefficacy, which is perceived behavioural control in TPB and perceived feasibility in SEE. The other two measures of TPB correspond to SEE's perceived desirability. Thus, it would appear that appropriate attitudes may not be enough. In this sense, SEE adds a volitional element to intentions: the propensity to act (Krueger et al., 2000) in order to capture the potential for identification and recognition of a credible new venture opportunity (Esfandiar et al., 2019). Acting upon credible entrepreneurial opportunities is vital given that favourable attitudes and social norms toward an EI are not sufficient to become intent to activate an entrepreneurial event.

In this sense, researchers in entrepreneurship agree to preserve that factors related to either individual variables like subjective traits and demographics or contextual variables such as social and cultural characters or financial facilitations affect people's pre-self-employment decisions (Passaro et al, 2017).

Each individual can value differently or give varying degree of importance to the same phenomenon. For this reason, external environment is believed to exert a direct influence over the three constructs that operate in the TPB model, while it only indirectly affects intent and behavior (Krueger et al., 2000). Also, Vliamos and Tzeremes (2012) indicate three types of factors that would affect the entrepreneurship, namely knowledge-based factors 
(education, skills and experience), behavioral factors (desire of independence and locus of control) and environmental factors (access to finance and the economic and institutional environment).

Based on the above arguments the analysis of EI remains an important issue nowadays, because of its importance to understand the phenomenon of entrepreneurship around the world.

\section{Empirical Analysis}

\section{Data}

To analyse EI, two databases from Global Entrepreneurship Monitor (GEM) were used: "Entrepreneurial Behaviour and Attitudes" and "Entrepreneurial Framework Conditions", available at https://www.gemconsortium.org/data. The Global Entrepreneurship Monitor (GEM) survey, is used to research entrepreneurial activity, attitudes, and perceptions in various countries and gathers data on entrepreneurial climate and self-perceptions about entrepreneurship (Acs et al., 2012; Haq et al., 2014; Beynon et al., 2017). We consider data from 2017, given that it is the last year available. From the original database containing 109 countries, we only selected those which had information available for all variables, resulting in a 52 countries list: 6 from Africa, 13 from Asia, 20 from Europe, 10 from Latin America and Caribbean, 2 from North America and 1 from Oceania. Appendix A contains the adapted GEM database used in this study.

\section{Method}

First, and in order to validate the hypotheses, Pearson's correlations were performed which shows an association between variables. Then, we used a multiple linear regression model with stepwise method in order to understand which variables, contribute significantly to explain entrepreneurial intentions (Teixeira et al., 2018). In the multiple linear regression, the existence of a linear relationship between the dependent variable and independent variables is assumed and the last one's are used to understand until what point they are explanatory or predictive for EI.

\section{Variables}

Dependent V ariable. The dependent variable is the Entrepreneurial Intentions (EI) measured as the Percentage of 18-64 population (individuals involved in any stage of entrepreneurial activity excluded) who are latent entrepreneurs and who intend to start a business within three years, as defined on GEM database.

Independent Variables. As independent variables, this study comprises ate the same time variables related to entrepreneurial behaviour and attitudes and variables related to entrepreneurial framework conditions. As previously mentioned, to understand the EI we must considerer ate the same time, economic and non-economic conditions, intrinsic and extrinsic factors and internal and external factors. The definition of all variables appears in Appendix B.

\section{Entrepreneurial Behaviour and Attitudes}

\section{Perceived Opportunities}

Stevenson and Jarillo (1990) view entrepreneurship as the pursuit of opportunity and they argue that perception of opportunities varies among people since an individual's desires and abilities are different from others. Opportunities will be external factors that favour or hamper the achievement of individuals' desires (Binney et al., 2003).

According to Shapero and Sokol (1982), understanding the entrepreneurial process requires an understanding of how credible opportunities are. When an entrepreneurial opportunity is perceived as credible, the volitional nature of intent means that one should feel a propensity to act upon the opportunity. In fact, it is believed that when propensity to act is high, the impact of perception of opportunity on EI becomes stronger, and vice versa (Esfandiar et al., 2019). Perceived start-up opportunities are increasingly considered the most distinctive, 
fundamental characteristic of entrepreneurship (Arenius and Minniti, 2005) and it can drive opportunity entrepreneurship (Beynon et al., 2017). As a result, the following hypothesis is proposed:

\section{H1: High levels of perceived opportunities by the individual positively influence EI.}

\section{Perceived Capabilities}

Therefore, from the perspective of becoming an entrepreneur, if opportunities do not exist, it is unlikely that the desired behaviour will be achieved despite great motivation on the part of an individual. So, it is also necessary to consider individuals' abilities, that is, their competencies that would favour the setting up of a business activity, since these will help individuals feel ready to achieve their goals (Binney et al., 2003; Rodriguez et al., 2017).

The way entrepreneurs view themselves, their self-confidence, the way they work, and their perceptions in general make them feel more confident when facing new challenges (Ros et al., 2017). Some authors such as Monllor and Altay (2016) group these factors together under the umbrella concept of self-efficacy. Self-efficacy defined simply as believing in one's own abilities and skills, is the key determinant of perceived feasibility of venture creation as it drives an optimistic self-view in the pursuit of goals (Esfandiar et al., 2019). That is, self-efficacy is an attribution of personal competence and control in a given situation and reflects the perception of a personal ability to carry out a specific job or task (Fernandes et al., 2018). Many studies have linked perceived capabilities and perceptions of entrepreneurs to greater intentions to start a business (Ajzen, 1991; Liñán, 2008; Ros et al., 2017). Then, we can conclude that the literature contains evidence of a clear, positive relationship between these characteristics and the intention to start a business (Ros et al., 2017). So, we formulate the following hypothesis:

\section{H2: High levels of perceived capacity by the individual positively influence EI.}

\section{Motivation}

Entrepreneurial attitude is characterized by motivation and determination to meet objectives, personal goals or aspirations shared by others in regard to work (Karcsics and Szakács, 2010). It is related to the so-called theories of needs, which identify individuals' internal stimuli (hunger, fear, etc.) that guide their behaviour (Miner, 1990; Rodriguez et al., 2017), and 'incentive theories', which suggest that individuals develop one behaviour or another in search of external objectives or prizes (Carsrud and Brännback, 2011; Fayolle et al., 2014; Rodriguez et al., 2017). Miner (1990), suppose that people with strong managerial motivation would be prompted to found firms and create strategies for their growth in order to have something to manage. He concludes that high task motivation people are attracted to entrepreneurship. Rodriguez et al. (2017), found that together with cultural aspects, individual motivation is an important explanatory factor in the entrepreneurial process. As referred by Carsrud and Brännback (2011) and Fayolle et al. (2014), motivation can influence the relationship between EI and the decision to be an entrepreneur. As a result, the following hypothesis is proposed:

\section{H3: Motivation positively influences EI.}

\section{Entrepreneurship as a Good Career Choice}

Career have been demonstrated, both theoretically and empirically, to be cognitive in nature (Krueger et al., 2000) which means that career-related decisions reflect a process in which beliefs, attitudes, and intentions advance as we cognitively process our knowledge, beliefs, and experiences (Lent et al. 1994). According Katz (1992), entrepreneurial careers fit this pattern.

Thus, career outcomes are influenced by personality and it seems that individuals with a certain personality are better able to become successful entrepreneurs than others (Konon and Kritikos, 2018). On the other hand, Lent et al. (2000) suggest that the individual's immediate personal environment (e.g., significant others like co-workers, friends and/or family) as well as the broader sociocultural context (e.g., societal culture) influence career choices. So, when it comes to career decisions, it thus seems plausible that culture would influence EI (Shiri et al., 2017). In this sense, Tripopsakul (2018), conclude that entrepreneurship as a desirable career choice significantly affected the level of EI. In summary, the following hypothesis can be formulated:

H4: Entrepreneurship as a Good Career Choice positively influence EI. 
High Status to Successful Entrepreneurs

The theory posits that intentions toward becoming an entrepreneur will depend on the perception that becoming an entrepreneur is within a person's competence and control and that becoming an entrepreneur is personally and socially desirable (Shepherd and Krueger, 2002; Mirjana et al., 2018). As previously mentioned, self-efficacy is an important determinant of successful entrepreneurial behaviour, as the incentive to act is greater when the entrepreneurs believe that their actions will have attainable results (Fernandes et al., 2018).

Mitchell et al. (2000), Mueller et al. (2002) and Tripopsakul (2018) concluded that external perceptions like high level status of successful entrepreneurs have a positively and significantly impact on EI. Based on this we propose the following hypothesis:

\section{H5: High status to successful entrepreneurs positively influences the EI.}

\section{Total Early-Stage Entrepreneurial Activity (TEA), Entrepreneurial Employee Activity and High Job Creation Expectation}

Shiri et al. (2017) pointed out that when entrepreneurship is perceived as desirable, is recognised in the public domain through the media, and is included in the higher education curriculum, it is more likely to be perceived as a desirable as well as attainable career option, not only among university graduates, but within society in general. Their results indicate that social valuation of entrepreneurship (both in society as a whole as well as in the individual's immediate environment) is positively related to individual attitudes towards entrepreneurship, subjective norm, and perceived behavioural control which ultimately impact individual career choice. Also, Koellinger (2008) points out that innovation and imitation in entrepreneurship coexist in all countries, and both types of entrepreneurial activity contribute to economic growth and countries' wealth. As referred by Ros et al. (2017) knowledge generated by established businesses is an important source of entrepreneurial opportunities. In this sense we expected that more entrepreneurship generates more entrepreneurship and we use three variables to measure this effect and postulate the following hypotheses:

\section{H6: Higher Total Early-Stage Entrepreneurial Activity (TEA) positively influences EI.}

H7: Higher Entrepreneurial Employee Activity positively EI.

H8: High Job Creation Expectation positively influences EI.

\section{Innovation}

As previously mentioned, entrepreneurship is the process to start a new business based on a product or a service. People immersed in this process are driven by the desire to innovate and change the way things are done (status quo). In last years, the scientific and technological innovation has established as one of the most important factors to ensure growth, competitiveness and high profitability businesses. There are several evidences for the importance of this issue and many studies support the view that innovation is the key to survival in competitive environments. New processes and products, new business models, creating new markets, attracting and retaining talent or enhance the image before partners, new customers and investors, represent some of the results of innovation (Cruz and Álvaro, 2013).

Mirjana et al. (2018), examines the influence of innovativeness on EI. The research was based on the presumption that individuals who are already more 'innovative' in terms of willingness to change, developing new solutions to problems or doing things differently, are also more willing to engage in entrepreneurial activities. Pernía et al. (2012), conclude that as both the economic and social value of new knowledge creation increase, the incentive to innovate should be higher, and vice versa. They also referred that in a process of creative construction, innovative entrepreneurs take advantage of existing knowledge, already generated (although underutilized) by incumbents, to create opportunities for innovation. Moreover, when starting a new venture, entrepreneurs eventually generate new knowledge, thus creating further opportunities for innovation that will be recognized and exploited by others. Therefore, the following hypothesis can be formulated: 


\section{Entrepreneurial Framework Conditions}

\section{Governmental Support and Policies and Governmental Programs}

As Amorósa et al. (2009) refers, public policies supporting entrepreneurship are diverse and have different objectives depending on the country. According Passaro et al. (2017), the entrepreneurial choice is somehow influenced by the specific external environmental like specific socioeconomic and demographic variables, facilitations or incentives descending from policies, as well as a correct functioning of institutions and markets. So, as to encourage the entrepreneurial activity, greater access to long-term resources which can be provided by the public administrations becomes a valuable instrument of economic policy. This leads to economic growth and employment and has an impact on entrepreneurial performance (Tabuenca et al., 2009). In this sense, we formulate the following hypotheses:

\section{H10: Governmental Support and Policies positively influence EI.}

H11: Governmental Programs positively influence EI.

\section{Financing for Entrepreneurs}

Public policies and programs that consider financing seems to be one of the major ways of achieving higher rates of entrepreneurial activity (Reynolds et al, 2005; Amorósa et al., 2009). However, obtaining access to outside financing is a significant challenge for nascent entrepreneurs (Honiga and Hoop, 2009). According Praag and Cramer (2001) and Tabuenca et al. (2009), the difference between the financial yield from the investment made by the businessman and the salary he could obtain if he chose to work as an employed person constitutes an essential factor when assuming the challenge of the risk of being self-employed or the creation of one's own company. In this respect, finance availability is one of the main conditions of the entrepreneurial framework (Acs, 2006; Amorósa et al., 2009). Rusu and Roman (2018) conclude that one of the most important factors affecting the entrepreneurial process it can be considered the access to a financial resource. These arguments generate the following hypothesis:

\section{H12: Financing for Entrepreneurs positively influence EI.}

\section{Basic School Entrepreneurial Education and Training}

The contribution of education to the development of an entrepreneurial culture is vital given that a strategy for entrepreneurship in education is a strategy for strengthening the individual's ability to exploit opportunities in business and industry and society generally (Vliamos, 2008). Bae et al. (2014) refer entrepreneurship education, as any pedagogical program or process of education for entrepreneurial attitudes and skills. A lot of studies conclude that graduates who are exposed to entrepreneurship education have huge potentials to become entrepreneurs (Amran et al., 2013; Eraut, 2004; Heinonen and Poikkijoki, 2006; Lautenschlager and Haase, 2011; Mohamad et al., 2015; Norfadhilah and Norasmah, 2012; Shariff and Norenzayan, 2011; Shelly and Seung, 2008). In this sense, developing entrepreneurship competence must be an integral part of education on all the levels. The educational system has a role to play when it comes to stimulate attitudes and behaviour promoting creativity and innovation in children and young persons (Vliamos, 2008). Building on this, the following research hypothesis is proposed:

\section{H13: Basic Education and training in entrepreneurship positively influence EI.}


Figure 1 presents the research modelling.

Figure: Research modeling.

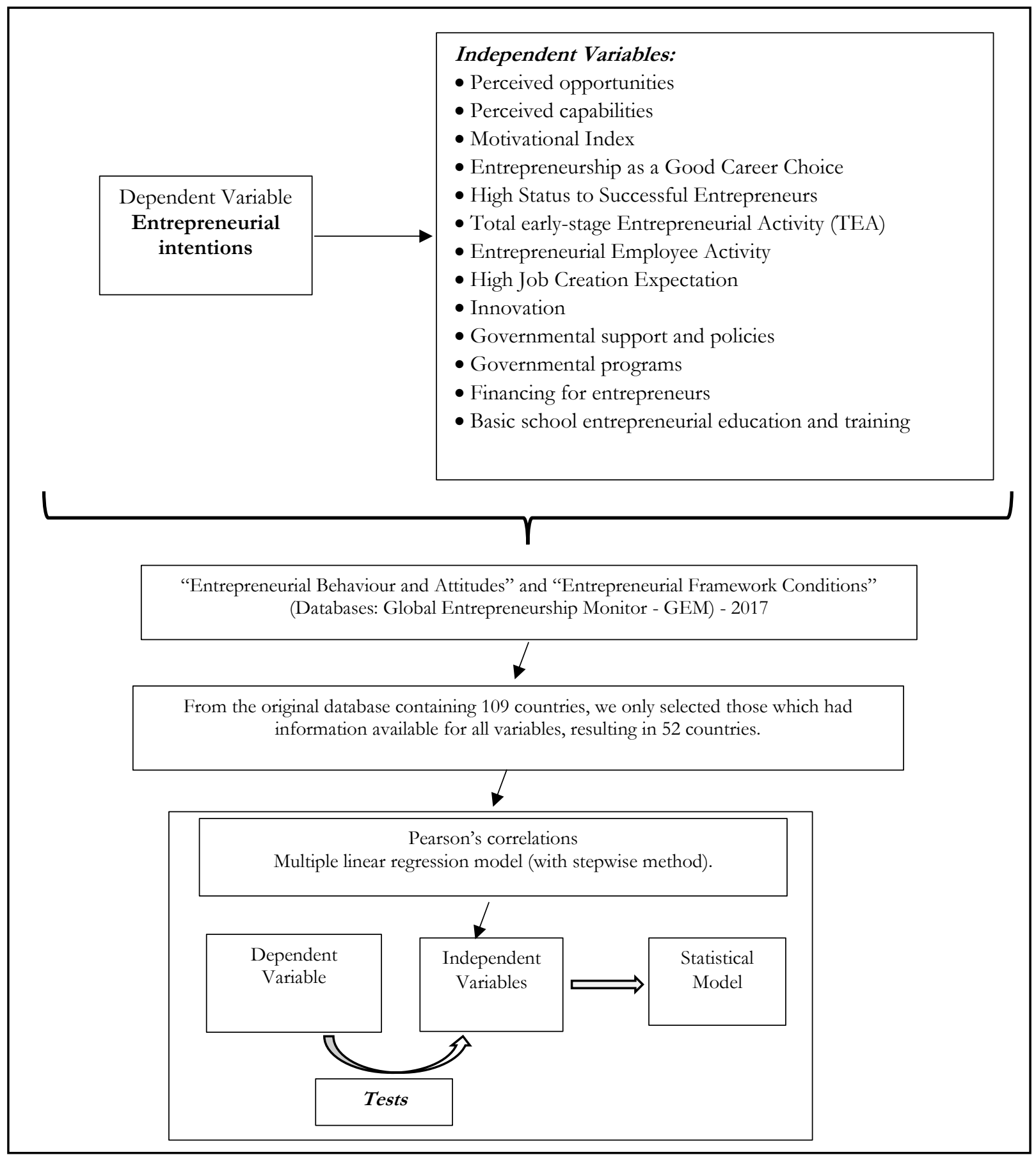

Source: Prepared by the authors. 


\section{Results}

\section{Univariate Analyses.}

Concerning the countries with greater frequency in relation to the variables we can observe that: United Arab Emirates has the highest "Entrepreneurial Intention" and "High Status to Successful Entrepreneurs", Sweden "Perceived Opportunities", Ecuador "Perceived Capabilities" and "TEA”, Netherlands "Motivational Index", "Government Programs" and "Basic school Entrepreneurial Education and Training", Guatemala "Entrepreneurship as Good Career Choice”, Estonia "Entrepreneurship Employ Activity”, Qatar "High Job Creation Expectation", Luxembourg "Innovation", Argentina “Government Support and Policies", and Indonesia "Financing for Entrepreneurs". Table 1 shows the descriptive statistics.

"Entrepreneurial Intention" (EI), shows a sharp and high dispersion of results with a coefficient of variation higher than $50 \%(14.74 / 21.57=0.68)$ which means a high variability of results from this sample with values between 3.67 and 56.33, corresponding to Japan and United Arab Emirates, respectively.

"Perceived Opportunities" (PO), has a coefficient of variation of 36\% $(15.31 / 43.07=0.36)$, and less than $50 \%$ of the respondents perceive good business opportunities. The extreme value for this variable corresponds to Sweden with approximate values than 79.49, and Japan to 7.41. From the initial analyses of these two variables we can conclude that Japan shows the lowest value of "EI" and "PO".

"Perceived Capabilities" (PC), has a lower coefficient of variation than "Perceived Opportunities" $(11.94 / 48.22=0.25)$ with a mean of 48.22 for all countries, which results that in general, the percentage of respondents with the ability to start a business are situated near 50\%. The highest value corresponds to Ecuador and the lowest again to Japan.

"Motivation" (MOTIV), measured by Motivational Index described as the percentage of those involved in TEA that are improvement-driven opportunity motivated, divided by the percentage of TEA that is necessity-motivated, confirms a sharp variation with values between 0.63 (Egypt) and 10.04 (Netherlands), with a coefficient of variation near $70 \%(2.16 / 3.07=0.70)$. It is important to refer that Netherlands shows a lower value of EI (8.11), and although a higher value of PO (64.09). However, Japan shows a value of motivation index of 3.35, higher than average.

"Entrepreneurship as a Good Career Choice" (EGCC), has a variation coefficient of 27\% (13.07/61.59=0.27). The percentage of population who agree with the statement that in their country, most people consider starting a business as a desirable career choice is below 50\%. This variable shows a mean of 61.59 with the highest value correspond to Guatemala (91.91) and the lowest to Puerto Rico (22.56).

"High Status to Successful Entrepreneurs" (HSSE), has a reduced coefficient of variation since it has a smaller dispersion of values $(10.06 / 68.46=0.15)$. We verified values between 47.43 (Argentina) and 87.77 (United Arab Emirates). To relieve that United Arab Emirates shows the highest value for EI and for HSSE.

“Total early-stage Entrepreneurial Activity” (TEA), shows a coefficient of variation near 50\% $(6.37 / 12.09=0.53)$, with a mean of 12.09. Ecuador is the country that have the highest TEA (29.62) and ate the same time the country with the higher PC. Bulgaria shows the lowest value (3.70).

"Entrepreneurial Employee Activity" (EEA), the rate of involvement of employees in entrepreneurial activities, has the highest value of coefficient of variation of our variables $(2.72 / 3.35=0.81)$, being verified values between 0.15 and 9.12, in which the largest country is Estonia and the smallest is Panama.

"High Job Creation Expectation" (HJCE), confirms a sharp variation, between 1.15 (Madagascar) and 45.02 (Qatar), with a coefficient of variation of $52 \%(16.65 / 20.29=0.52)$.

"Innovation" (INNOV), has also a sharp variation (Panama $=8.51$ and Luxembourg $=57.13)$. The coefficient of variation is $39 \%(10.39 / 26.39=0.39)$. Panama also has the lowest HJCE and the lowest EEA. 
"Governmental Support and Policies" (GSP), "Governmental Programs" (GP) and "Financing for Entrepreneurs" (FIN) has the same coefficient of variation, near 20\% showing values for mean equal to 2.62 for GSP, 2.66 for GP and 2.60 for FIN. The highest values correspond to Argentina (3.75), Netherlands (3.63) and Indonesia (3.71) and the lowest to Guatemala (1.56), Iran (1.34) and also Guatemala (1.62), respectively.

Table 1 - Descriptive Statistics

\begin{tabular}{|c|c|c|c|c|c|c|c|c|c|c|}
\hline \multirow[b]{2}{*}{$\begin{array}{l}\text { Entrepreneurial } \\
\text { intentions }\end{array}$} & \multirow{2}{*}{$\begin{array}{l}\mathrm{N} \\
52\end{array}$} & \multirow{2}{*}{$\begin{array}{c}\text { Minimum } \\
3.67\end{array}$} & \multirow{2}{*}{$\begin{array}{c}\text { Maximum } \\
56.33\end{array}$} & \multirow{2}{*}{$\begin{array}{c}\text { Sum } \\
1121.67\end{array}$} & \multirow{2}{*}{$\begin{array}{l}\text { Mean } \\
21.57\end{array}$} & \multirow{2}{*}{$\begin{array}{c}\begin{array}{c}\text { Std. } \\
\text { Deviation }\end{array} \\
14.74\end{array}$} & \multicolumn{2}{|c|}{ Skewness } & \multicolumn{2}{|c|}{ Kurtosis } \\
\hline & & & & & & & 0.97 & 0.33 & -0.17 & 0.65 \\
\hline Perceived opportunities & 52 & 7.41 & 79.49 & 2239.88 & 43.07 & 15.31 & 0.08 & 0.33 & 0.26 & 0.65 \\
\hline Perceived capabilities & 52 & 10.77 & 74.06 & 2507.69 & 48.22 & 11.94 & -0.29 & 0.33 & 1.13 & 0.65 \\
\hline Motivational Index & 52 & 0.63 & 10.04 & 159.39 & 3.07 & 2.16 & 1.59 & 0.33 & 2.31 & 0.65 \\
\hline $\begin{array}{l}\text { Entrepreneurship as a } \\
\text { Good Career Choice }\end{array}$ & 52 & 22.56 & 91.91 & 3202.70 & 61.59 & 13.05 & -0.51 & 0.33 & 1.60 & 0.65 \\
\hline $\begin{array}{l}\text { High Status to Successful } \\
\text { Entrepreneurs } \\
\text { Total early-stage }\end{array}$ & 52 & 47.43 & 87.77 & 3559.94 & 68.46 & 10.06 & -0.44 & 0.33 & -0.40 & 0.65 \\
\hline $\begin{array}{l}\text { Entrepreneurial Activity } \\
\text { (TEA) }\end{array}$ & 52 & 3.70 & 29.62 & 628.51 & 12.09 & 6.37 & 0.90 & 0.33 & 0.08 & 0.65 \\
\hline $\begin{array}{l}\text { Entrepreneurial } \\
\text { Employee Activity }\end{array}$ & 52 & 0.15 & 9.12 & 174.25 & 3.35 & 2.72 & 0.72 & 0.33 & -0.79 & 0.65 \\
\hline $\begin{array}{l}\text { High Job Creation } \\
\text { Expectation }\end{array}$ & 52 & 1.15 & 45.02 & 1055.02 & 20.29 & 10.65 & 0.22 & 0.33 & -0.54 & 0.65 \\
\hline Innovation & 52 & 8.51 & 57.13 & 1372.16 & 26.39 & 10.39 & 0.89 & 0.33 & 1.23 & 0.65 \\
\hline $\begin{array}{l}\text { Governmental support } \\
\text { and policies }\end{array}$ & 52 & 1.56 & 3.75 & 136.12 & 2.62 & 0.53 & 0.43 & 0.33 & -0.37 & 0.65 \\
\hline Governmental programs & 52 & 1.34 & 3.63 & 138.18 & 2.66 & 0.53 & -0.13 & 0.33 & -0.75 & 0.65 \\
\hline $\begin{array}{l}\text { Financing for } \\
\text { entrepreneurs }\end{array}$ & 52 & 1.62 & 3.71 & 135.32 & 2.60 & 0.49 & 0.17 & 0.33 & -0.54 & 0.65 \\
\hline $\begin{array}{l}\text { Basic school } \\
\text { entrepreneurial education } \\
\text { and training }\end{array}$ & 52 & 1.22 & 3.40 & 102.06 & 1.96 & 0.46 & 1.13 & 0.33 & 1.43 & 0.65 \\
\hline
\end{tabular}

"Basic school entrepreneurial education and training" (BS), the extent to which training in creating or managing SMEs is incorporated within the education and training system at primary and secondary levels is more prominent in Netherlands (3.40) and shows a mean of 1.96. The coefficient of variation has a value of $24 \%(0.46 / 1.96=0.24)$. The lowest value appears in Egypt (1.22). It is important to refer that Netherlands also shows the highest values for MOTIV and GP.

\section{Correlation Analyses}

The results of Pearson's correlations can be observed in Table 2.

It is observed that the correlations between "PC" with "EI" $(\mathrm{r}=0.672, \mathrm{p}<0.01)$, "EGCC" with "EI" ( $\mathrm{r}=0.464$, $\mathrm{p}<0.01)$, "HSSE" with "EI" ( $r=0.326, \mathrm{p}<0.05)$, "TEA" with "EI" $(\mathrm{r}=0.620, \mathrm{p}<0.01)$ have statistical significance, that is the correlation that is established between them is positive and significant, so it is concluded that H2, H4, $\mathrm{H} 5$ and $\mathrm{H} 6$ are validated. In this sense we can conclude that "PC", "EGCC", "HSSE" and "TEA" positively influences "EI".

The correlation between "FIN" with "EI" $(\mathrm{r}=-0.319, \mathrm{p}<0.05)$ is also statistically significant but the sign of correlation is negative which means that more financing for entrepreneurs have a negative effect on Entrepreneurial Intentions. This result is consistent with Hurst and Lusardi (2004), Kim et al. (2006) and Mueller (2006) which conclude that access to financial resources is not considered to be a problem by the earliest stage businesses because they usually do not use large amounts of financial capital, and the creation of new firms will continue even if their access to financial resources will be vulnerable. Rusu and Roman (2018), also conclude that the relationship between access to financial resources and entrepreneurship might be different according to the reason why a person becomes an entrepreneur. So, we don't validate H12. 
Although not significant, there are negative correlations between the variables "MOTIV", "EEA", "INNOV", "GSP", "GP" and "BS" with "EI", and therefore H3, H7, H9, H10, H11 and H13 are not validated. This difference in results from what we postulate could be due to possible cultural variances around the world (Rodrigues et al., 2017).

In relation to "PO" with "EI" and "HJCE" with "EI" there is a positive but week correlation, so H1 and H8 are also not validated. It should be noted that there is a very significant positive correlation between variables whose hypotheses have not even been raised.

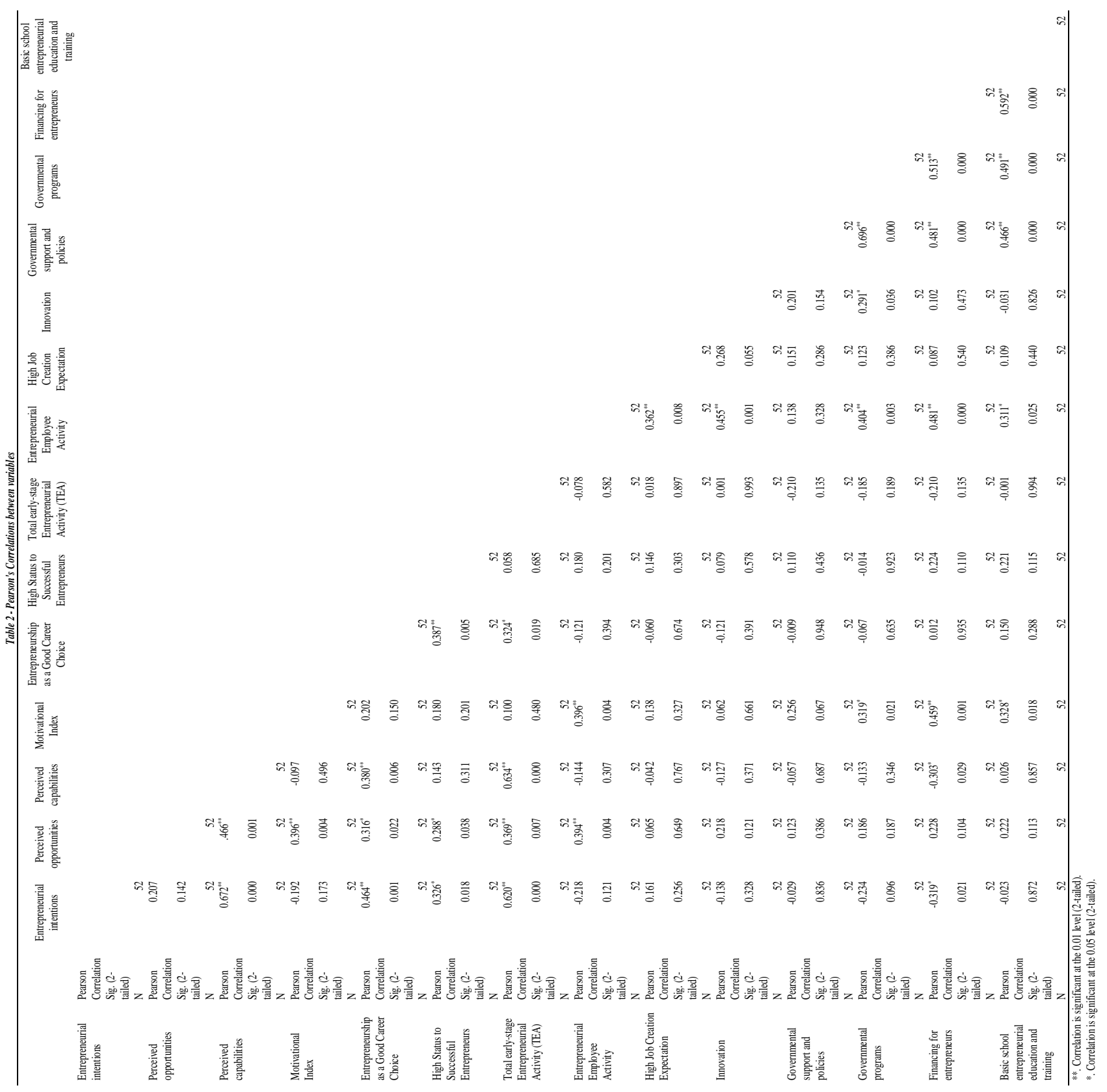




\section{Linear Regression}

To explain "EI", 13 dependent variables were introduced and through the Stepwise method, after 4 iterations, following significant model $(\mathrm{F}=20.161, \mathrm{p}<0.001)$ was obtained with the inclusion of 4 variables (Table 3 and 4$)$. Thus, the most important variables are "PC", "TEA", "HSSE" and "MOTIV" as they present less weight in the equation (though the analysis of standardized coefficients).

Table 3 - Variables Entered/Removed ${ }^{a}$

\begin{tabular}{|c|c|c|c|}
\hline MModel & Variables Entered & $\begin{array}{l}\text { Variables } \\
\text { Removed }\end{array}$ & Method \\
\hline 1 & Perceived capabilities & & $\begin{array}{l}\text { Stepwise (Criteria: Probability-of-F-to-enter }<=.050 \text {. Probability-of-F- } \\
\text { to-remove }>=.100) .\end{array}$ \\
\hline 2 & $\begin{array}{l}\text { Total early-stage Entrepreneurial } \\
\text { Activity (TEA) }\end{array}$ & & $\begin{array}{l}\text { Stepwise (Criteria: Probability-of-F-to-enter }<=.050 \text {. Probability-of-F- } \\
\text { to-remove }>=.100) .\end{array}$ \\
\hline 3 & $\begin{array}{l}\text { High Status to Successful } \\
\text { Entrepreneurs }\end{array}$ & & $\begin{array}{l}\text { Stepwise (Criteria: Probability-of-F-to-enter }<=.050 \text {. Probability-of-F- } \\
\text { to-remove }>=.100 \text { ). }\end{array}$ \\
\hline 4 & Motivational Index & & $\begin{array}{l}\text { Stepwise (Criteria: Probability-of-F-to-enter }<=.050 \text {. Probability-of-F- } \\
\text { to-remove }>=.100) .\end{array}$ \\
\hline
\end{tabular}

a. Dependent Variable: Entrepreneurial intentions

Table 4 - ANOVAa

\begin{tabular}{|c|c|c|c|c|c|c|}
\hline & Model & $\begin{array}{l}\text { Sum of } \\
\text { Squares }\end{array}$ & df & $\begin{array}{r}\text { Mean } \\
\text { Square }\end{array}$ & F & Sig. \\
\hline \multirow{3}{*}{1} & Regression & 5002.678 & 1 & 5002.678 & 41.152 & $.000^{\mathrm{b}}$ \\
\hline & Residual & 6078.285 & 50 & 121.566 & & \\
\hline & Total & 11080.963 & 51 & & & \\
\hline \multirow{3}{*}{2} & Regression & 5702.876 & 2 & 2851.438 & 25.980 & $.000^{\mathrm{c}}$ \\
\hline & Residual & 5378.086 & 49 & 109.757 & & \\
\hline & Total & 11080.963 & 51 & & & \\
\hline \multirow{3}{*}{3} & Regression & 6356.956 & 3 & 2118.985 & 21.531 & $.000^{\mathrm{d}}$ \\
\hline & Residual & 4724.007 & 48 & 98.417 & & \\
\hline & Total & 11080.963 & 51 & & & \\
\hline \multirow{3}{*}{4} & Regression & 7000.766 & 4 & 1750.192 & 20.161 & $.000^{\mathrm{e}}$ \\
\hline & Residual & 4080.197 & 47 & 86.813 & & \\
\hline & Total & 11080.963 & 51 & & & \\
\hline
\end{tabular}

a. Dependent Variable: Entrepreneurial intentions

b. Predictors: (Constant), Perceived capabilities

c. Predictors: (Constant), Perceived capabilities, Total early-stage Entrepreneurial Activity (TEA)

d. Predictors: (Constant), Perceived capabilities, Total early-stage Entrepreneurial Activity (TEA),

High Status to Successful Entrepreneurs

e. Predictors: (Constant), Perceived capabilities, Total early-stage Entrepreneurial Activity (TEA),

High Status to Successful Entrepreneurs, Motivational Index

The assumption of the model was analysed, namely the normal distribution, homogeneity and independence of errors. The first two assumptions were validated graphically (Appendix $\mathrm{C}$ ) and the independence assumption was validated using Durbin-Watson statistic ( $\mathrm{d}=1.931)$, as can be seen in the table 5 . 
Table 5 - Model Summarye

\begin{tabular}{|c|c|c|c|c|c|c|c|c|c|c|}
\hline \multirow{2}{*}{ Model } & \multirow{2}{*}{$\mathbf{R}$} & \multirow{2}{*}{\multicolumn{2}{|c|}{$\begin{array}{c}\mathbf{R} \underset{\text { Square }}{\mathbf{d} \text { iquare }} \\
\text { Square }\end{array}$}} & \multirow{2}{*}{$\begin{array}{c}\text { Std. } \\
\text { Error of } \\
\text { the } \\
\text { Estimate }\end{array}$} & \multicolumn{5}{|c|}{ Change Statistics } & \multirow[t]{2}{*}{$\begin{array}{l}\text { Durbin- } \\
\text { Watson }\end{array}$} \\
\hline & & & & & R Squar & $\begin{array}{c}\mathrm{F} \\
\text { Change } \\
\end{array}$ & df1 & df2 & $\begin{array}{c}\text { Sig. F } \\
\text { Change }\end{array}$ & \\
\hline 1 & & $\left..672^{\mathrm{a}}\right) .451$ & 0.440 & 11.02568 & 0.451 & 41.152 & 1 & 50 & 0.000 & \\
\hline 2 & & $\left..717^{b}\right) .515$ & 0.495 & 10.47649 & 0.063 & 6.380 & 1 & 49 & 0.015 & \\
\hline 3 & & .757 c $) .574$ & 0.547 & 9.92052 & 0.059 & 6.646 & 1 & 48 & 0.013 & \\
\hline 4 & & $\left..795^{d}\right) .632$ & 0.600 & 9.31733 & 0.058 & 7.416 & 1 & 47 & 0.009 & 1.931 \\
\hline
\end{tabular}

a. Predictors: (Constant), Perceived capabilities

b. Predictors: (Constant), Perceived capabilities, Total early-stage Entrepreneurial Activity (TEA)

c. Predictors: (Constant), Perceived capabilities, Total early-stage Entrepreneurial Activity (TEA), High Status to Successful Entrepreneurs

d. Predictors: (Constant), Perceived capabilities, Total early-stage Entrepreneurial Activity (TEA), High Status to Successful Entrepreneurs, Motivational Index

e. Dependent Variable: Entrepreneurial intentions

VIF was used to diagnose multicollinearity, being verified through the tolerance values (which should be superior to 0,1 ) and the VIF (Variance Inflation Factor, which should be inferior to 5 or at 10). Based on Table 6 (coefficients) we can conclude that there are no problems of multicollinearity.

Table 6 - Coefficients ${ }^{a}$

\begin{tabular}{|c|c|c|c|c|c|c|c|c|}
\hline & \multirow[t]{2}{*}{ Model } & \multicolumn{2}{|c|}{$\begin{array}{c}\text { Unstandardized } \\
\text { Coefficients }\end{array}$} & \multirow{2}{*}{\begin{tabular}{|l|}
$\begin{array}{l}\text { Standardized } \\
\text { Coefficients }\end{array}$ \\
Beta
\end{tabular}} & \multirow[t]{2}{*}{$\mathbf{t}$} & \multirow[t]{2}{*}{ Sig. } & \multicolumn{2}{|c|}{ Collinearity Statistics } \\
\hline & & B & Std. Error & & & & Tolerance & VIF \\
\hline \multirow{2}{*}{1} & (Constant) & -18.418 & 6.418 & & -2.870 & 0.006 & & \\
\hline & Perceived capabilities & 0.829 & 0.129 & 0.672 & 6.415 & 0.000 & 1.000 & 1.000 \\
\hline \multirow{4}{*}{2} & (Constant) & -15.244 & 6.227 & & -2.448 & 0.018 & & \\
\hline & Perceived capabilities & 0.575 & 0.159 & 0.466 & 3.620 & 0.001 & 0.598 & 1.672 \\
\hline & Total early-stage & 0.752 & 0.298 & 0.325 & 2.526 & 0.015 & 0.598 & 1.672 \\
\hline & $\begin{array}{l}\text { Entrepreneurial } \\
\text { Activity (TEA) }\end{array}$ & & & & & & & \\
\hline \multirow{7}{*}{3} & (Constant) & -37.667 & 10.508 & & -3.585 & 0.001 & & \\
\hline & Perceived capabilities & 0.521 & 0.152 & 0.422 & 3.430 & 0.001 & 0.587 & 1.705 \\
\hline & Total early-stage & 0.784 & 0.282 & 0.339 & 2.776 & 0.008 & 0.597 & 1.675 \\
\hline & $\begin{array}{l}\text { Entrepreneurial } \\
\text { Activity (TEA) }\end{array}$ & & & & & & & \\
\hline & High Status to & 0.360 & 0.140 & 0.246 & 2.578 & 0.013 & 0.978 & 1.023 \\
\hline & Successful & & & & & & & \\
\hline & Entrepreneurs & & & & & & & \\
\hline \multirow{9}{*}{4} & (Constant) & -35.032 & 9.916 & & -3.533 & 0.001 & & \\
\hline & Perceived capabilities & 0.426 & 0.147 & 0.345 & 2.898 & 0.006 & 0.553 & 1.807 \\
\hline & Total early-stage & 0.949 & 0.272 & 0.410 & 3.488 & 0.001 & 0.567 & 1.763 \\
\hline & Entrepreneurial & & & & & & & \\
\hline & Activity (TEA) & & & & & & & \\
\hline & High Status to & 0.437 & 0.134 & 0.298 & 3.258 & 0.002 & 0.934 & 1.070 \\
\hline & Successful & & & & & & & \\
\hline & Entrepreneurs & & & & & & & \\
\hline & Motivational Index & -1.733 & 0.636 & -0.253 & -2.723 & 0.009 & 0.905 & 1.105 \\
\hline
\end{tabular}

a. Dependent Variable: Entrepreneurial intentions
The multiple linear regression allowed to identify the variables "PC", "TEA", "HSSE" and "MOTIV" as significant predictors of "EI", which means that they are the most important variables. The model is significant, robust and explains $60 \%$ of the variance in values of "EI".

\section{Conclusion}

Entrepreneurship is well-thought-out a substantial and central factor for the economic growth of a country, so it must be a national priority for many governments around the world. In this context, it's important to understand how people decide to undertake a new venture and examining the factors that affects their decisions. To comprehend people propensity towards the entrepreneurial choice researchers focuses on the study of EI.

Considering the above arguments, the objective of this paper is to explain EI in the world using, simultaneously, behaviour, attitudes and framework conditions. Thus, we use some variables available in GEM. The results of 
correlations show that "Perceived Capabilities", "Entrepreneurship as a Good Career Choice", "High Status to Successful Entrepreneurs" and "Total Early-Stage Entrepreneurial Activity" positively and significantly influence "Entrepreneurial Intentions". Then, we can conclude that exists an association between these variables, and that they have a high level of significance that explains EI. Concerning multiple linear regression, we can postulate that "Perceived Capabilities", "Total Early-Stage Entrepreneurial Activity", "High Status to Successful Entrepreneurs" and "Motivation" are the variables that best explains and predicts the EI. It is important to refer that none of the variables considering framework conditions entered in the model. This can be due to differences between cultures and established government policies around the world. Then we can conclude that the vision of entrepreneurship across the world possibly depends on external environment in which the individual is inserted.

Intent plays an important role as a bridge in linking individual motivation with entrepreneurial behaviours, which decides the implementation of entrepreneurial behaviour. Entrepreneurial intentions are affected simultaneously by objective and subjective factors, which also determine the entrepreneurial attitude.

The entrepreneurial environment is a type of external driving force that influences individual cognition of the external environment. Also, it takes into account the availability of resources, government intervention and entrepreneurial attitude where the external factors that affect business activities have emotional environmental elements and rational environmental elements.

Entrepreneurial intentions are influenced by internal and external forces. Internal forces include business objectives, qualities and skills, while the main external influence is the business environment. Strong business goals, good business qualities and high business skills can relatively promote the updating of entrepreneurial trends as well as the business environment. Entrepreneurial attitudes have the effect stimulated by motivation, combined effect of skill and restrictive external effect of the environment in promoting entrepreneurial intentions.

Like all studies, this one has certain limitations that further research should overcome. One possible limitation is the use of data only from one year. Countries policies and economic conditions vary all the time and the factors that motivate entrepreneurship and that facilitates entrepreneurial intentions can be influenced by that conditions. For future, researchers should consider if the decision of becoming an entrepreneur is for necessity or opportunity and verify if the results are the same with the variables used in this study.

\section{References}

ACS, Z. How is Entrepreneurship Good for Economic Growth? Innovations Journal, v. 1, p. 97-107 2006.

ACS, Z.; BROOKSBANK, D.; O'GORMAN, P. D.; TERJENSES, S. The knowledge spill over theory of entrepreneurship: An application to foreign direct investment, International Journal of Entrepreneurship and Small Business, v. 5, n. 2, p. 237-261, 2012.

AJZEN, I. The theory of planned behaviour", Organizational Behaviour and Human Decision Processes, v. 50, n. 2, p. 179-211, 1991.

Al-JUBARI, I.; HASSAN, A.; LIÑÁN, F. Entrepreneurial intention among University students in Malaysia: integrating self-determination theory and the theory of planned behaviour, International Entrepreneurship and Management Journal, p. 1-20, 2018.

AMORÓSA, J. E.; ATIENZAB, M.; ROMANÍC, G. Financing entrepreneurial activity in Chile: scale and scope of public support programs, Venture Capital, v. 11, n. 1, p. 55-70, 2009.

AMRAN, M. R.; SAIF, U.; SHAGHAYEH, R., K.; SAMRENA, M. J. Factors affecting entrepreneurial intention among graduate students of Universiti Teknologi Malaysia, International Journal of Business and Social Science, v. 4, n. 2, p. 182-188, 2013.

ARENIUS, P.; MINNITI, M. Perceptual variables and nascent entrepreneurship, Small Business Economics, v. 24, n. 3, p. 233-247, 2005.

BAE, T. J.; QIAN, S.; MIAO C.; FJET, J. O. The Relationship Between Entrepreneurship Education and Entrepreneurial Intentions: A Meta-Analytic Review, Entrepreneurship Theory and Practice, v. 38, n. 2, p. 217-254, 2014.

BEYNON, M. J.; JONES, P.; PICKERNELL, D. Entrepreneurial climate and self-perceptions about entrepreneurship: a country comparison using fsQCA with dual outcomes, Journal of Business Research, v. 89, p. 418-428, 2017.

BINNEY, W.; HALL, J.; SHAW, M. A. further development in social marketing application of the MOA framework an behavioural implications, Marketing Theory, v. 3, n. 3, p. 387-403, 2003. 
CARSRUD, A. L.; BRANNBACK, M. Entrepreneurial motivations: What do we still need to know? Journal of Small Business Management, v. 49, n. 1, p. 9-26, 2011.

CRESPO, N. F.; BELCHIOR, R.; COSTA, E. B. (2018). Exploring individual differences in the relationship between entrepreneurial self-efficacy and intentions: Evidence from Angola, Journal of Small Business and Enterprise Development, https://doi.org/10.1108/JSBED-03-2017-0105. Access on November 14, 2018.

CRUZ, E. F. Z.; ÁLVAROl, A. (2013). Introduction of Entrepreneurship and Innovation subjects in a Computer Science course in Brazil, Paper presented at the 2013 IEEE Frontiers in Education Conference (FIE).

ERAUT, M. Informal learning in the workplace, Studies in Continuing Education, v. 26, n. 2, p. 35-57, 2004.

ESFANDIAR, K.; TEHRANI, M. S; PRATT, S.; ALTINY, L. Understanding entrepreneurial intentions: A developed integrated structural model approach, Journal of Business Research, v. 94, p. 172-182, 2019.

FAYOLLE, A.; LIÑÁN, F.; MORIANO, J. Beyond entrepreneurial intentions: Values and motivations in entrepreneurship, International Entrepreneurship and Management Journal, v. 10, n. 4, p. 679-689, 2014.

FERNANDES, C.; FERREIRA, J. J.; RAPOSO, M.; SANCHEZ, J.; SANCHEZ, B. H. Determinants of entrepreneurial intentions: an international cross-border study, International Journal of Innovation Science, v. 10, n. 2, p. 129-142, 2018.

HAQ, M. A.; USMAN, M; HUSSAIN, N.; ANJUM, Z. Entrepreneurial activity in China and Pakistan: a GEM data evidence, Journal of Entrepreneurship in Emerging Economies, v. 6, n. 2, p. 179-193, 2014.

HEINONEN, J.; POIKKIJOKI, A. A. An entrepreneurial-directed approach to entrepreneurship education: mission impossible? Journal of Management Development, v. 25, n. 1, p. 80-94, 2006.

HONINGA, B.; HOPP, C. Learning orientations and learning dynamics: Understanding heterogeneous approaches and comparative success in nascent entrepreneurship, Journal of Business Research, v. 94, p. 28-41, 2019.

HURST, E.; LUSARDI, A. Liquidity constraints, household wealth, and entrepreneurship, Journal of Political Economy, v. 112, n. 2, p. 319-347, 2004.

KARCSICS, E.; SZAKÁCS, F. Personality factors of entrepreneurial competitiveness, Society and Economy, v. 32 , n. 2, p. 277-295, 2010.

KARIMI, S.; BIEMANSI, H. J.A.; MAHDEI, K. N.; LANS, T.; CHIZARI, M.; MULDER, M. Testing the relationship between personality characteristics, contextual factors and entrepreneurial intentions in a developing country, International Journal of Psychology, v. 52, n. 3, p. 227-240, 2015.

KATZ, J. Modelling entrepreneurial career progressions: Concepts and considerations, Entrepreneurship Theory and Practice, v. 19, n. 2, p. 23-39, 1992.

KHALIFA, A. H.; DHIAF, M. M. The impact of entrepreneurship education on entrepreneurial intention: the UAE context, Polish Journal of Management Studies, v. 14, n. 1, p. 119-128, 2016.

KIM, P.H.; ALDRICH, H.E.; KEISER, L.A. Access (not) denied: The impact of financial, human, and cultural capital on entrepreneurial entry in the United States, Small Business Economics, v. 27, n. 1, p. 5-22, 2006.

KOELLINGER, P. Why are some entrepreneurs more innovative than others? Small Business Economics, v. 31, p. 21-37, 2008.

KONON, A.; KRITIKOS, A. S. Prediction based on entrepreneurship-prone personality profiles: sometimes worse than the toss of a coin, Small Business Economics, Article in press. (2018).

KRUEGER, N. F.; REILLY, M. D.; CARSRUD, A. L. Competing models of entrepreneurial intentions, Journal of Business Venturing, v. 15, p. 411-432, 2000.

LAUTENSCHLAGER, A.; HAASE, H. The myth of entrepreneurship education: Seven Arguments against teaching business creation at universities, Journal of Entrepreneurship Education, v. 14, p. 147-161, 2011.

LENT, R.; STEVEN, W. B; GAI, D. H. Toward a unifying social cognitive theory of career and academic interest, choice, and performance, Journal of Vocational Behaviour, v. 45, n. 1, p. 79-122, 1994.

LENT, R.; STEVEN, W. B.; GAI, D. H., Contextual supports and barriers to career choice: a social cognitive analysis, Journal of Counselling Psychology, v. 47, p. 36-49, 2000.

LIÑÁN, F. Skill and value perceptions: How do they affect entrepreneurial intentions? International Entrepreneurship and Management Journal, v. 4, n. 3, p. 257-272, 2008.

MIRJANA, P. B.; ANA, A.; MARJANA M. S. Examining determinants of entrepreneurial intentions in Slovenia: applying the theory of planned behaviour and an innovative cognitive style, Economic Research-Ekonomska Istraživanja, v. 31, n. 1, p. 1453-1471, 2018.

MINER, J. B. Entrepreneurs, high grow entrepreneurs, and managers: contrasting and overlapping motivational patters, Journal of Business Venturing, v. 5, p. 221-234, 1990.

MITCHELL, R.K.; SMITH, B.; SEAWRIGHT, K.W.; MORSE E.A. Cross-cultural cognitions and the venture creation decision, Academy of Management Journal, v. 43, n. 5, p. 974-993, 2000.

MOHAMAD, N.; YUSOF, N.; SOON, J. Estimating the effect of entrepreneur education on graduates' intention to be entrepreneurs, Education + Training, v. 57, n. 8/9, p. 874-890, 2015.

MONLLOR, J.; ALTAY, N. Discovering opportunities in necessity: The inverse creative destruction effect, Journal of Small Business and Enterprise Development, v. 23, n. 1, p. 274-291, 2016. 
MORIANO, J. A.; GORGIEVSKI, M.; LAGUNA, M.; STEPHAN, U.; ZARAFSHANI, K. (2011). A cross cultural approach to understanding entrepreneurial intention, Journal of Career Development, 38(1), 1-24.

MUELLER, P. Entrepreneurship in the region: breeding ground for nascent entrepreneurs? Small Business Economics, v. 27, n. 1, p. 41-58, 2006.

MUELLLER, S.L.; THOMAS A.S.; JAEGER A.MNational entrepreneurial potential: the role of culture, economic development, and political history, Advances in Comparative International Management, v. 14, p. 221-257, 2002.

NORFADHILAH, N.; NORASMAH, O. (2012). Evaluation of Polytechnic entrepreneurship programs in Malaysia, International Journal of Trade, Economics and Finance, v. 3, n. 5, p. 356- 362, 2012.

PASSARO, R.; SCANDURRA, G.; THOMAS, A. The Emergence of Innovative Entrepreneurship: Beyond the Intention - Investigating the Participants in an Academic SUC, International Journal of Innovation and Technology Management, v. 14, n. 5, p. 1-22, 2017.

PERNÍA, J. L. G.; LEGAZKUE, I. P.; HERRERO, F. V. Innovation, entrepreneurial activity and competitiveness at a sub-national level, Small Business Economics, v. 39, p. 561-574, 2012.

PRAAG, C.M.; CRAMER, J. S. The Roots of Entrepreneurship and Labour Demand: Individual Ability and Low Risk Aversion, Economica, v. 68, n. 269, p. 45-62, 2001.

POTISHUK, V.; KRATZER, J. Factors affecting entrepreneurial intentions and entrepreneurial attitudes in higher education, Jou;nal of Entrepreneurship Education, v. 20, n. 1, p. 25-44, 2017.

REYNOLDS, P.; BOSMA, N.; AUTIO, E.; HUNT, S.; De BONO, N.; SERVAIS, I.; LÓPEZ-GARCIA, P.; CHIN, N., Global Entrepreneurship Monitor: data collection design and implementation 1998-2003, Small Business Economics, v. 24, p. 205-31, 2005.

ROBICHAUD, Y.; LeBRASSEUR, R.; NAGARAJAN, K.V. Necessity and Opportunity-driven Entrepreneurs in Canada: An Investigation into their Characteristics and an Appraisal of the Role of Gender, The Journal of Applied Business and Economics, v. 11, n. 1, p. 1-59, 2010.

RODRIGUEZ, F. J. G.; SOTO, E. G.; ROSA, I. R.; TAÑO, D. G. Entrepreneurial process in peripheral regions: the role of motivation and culture, European Planning Studies, v. 25, n. 11, p. 2037-2056, 2017.

ROS, S. C.; GARZÓN, D.; TUR, A. M. Entrepreneurial competencies and motivations to enhance marketing innovation in Europe, Psychology and Marketing, v. 34, n. 11, p. 1031-1038, 2017.

RUSU, V. D.; ROMAN, A. Entrepreneurial Motivations in the European Union Countries: An Empirical Approach, Management Dynamics in the Knowledge Economy, v. 6, n. 1, p. 9-31, 2018.

SHAPERO, A.; SOKOL, L. The social dimensions of entrepreneurship, In C. Kent, D. Sexton, \& K. H. Vesper (Eds.). The encyclopedia of entrepreneurship (pp. 72-90). Englewood Cliffs, NJ: Prentice-Hall. 1982.

SHARIFF, A. F.; NORENZAYAN, A. Mean gods make good people: Different views of God predict cheating behaviour, International Journal for the Psychology of Religion, v. 21, p. 85-96, 2011.

SHELLY, A. B.; SEUNG, Y. C. Factors that influence informal learning in the workplace, Journal of Workplace Learning, v. 20, n. 4, p. 229-244, 2008.

SHEPHERD, D. A.; KRUEGER, N. F., An intentions-based model of entrepreneurial teams' social cognition, Entrepreneurship Theory and Practice, v. 27, n. 2, p. 167-185, 2002.

SHIRI, N.; SHINNAR, R. S.; MIRAKZADEH, A. A.; ZARAFSHANI, K. Cultural values and entrepreneurial intentions among agriculture students in Iran, International Entrepreneurship and Management Journal, v. 13, n. 4, p. 1157-1179, 2017.

SMITH-HUNTER, A.; KAPP, J.; YONKERS, V. A psychological model of entrepreneurial behaviour, Journal of Academy of Business and Economics, v. 2, n. 2, p. 180-192, 2003.

STEVENSON, H. H.; JARILLO, J. C. A paradigm of entrepreneurship: Entrepreneurial Management, Strategic Management Journal, v. 11, n. 4, p. 17-27, 1990.

TABUENCA, A. G.; ESPERT, J. L. C.; ROUR, A J. R. C. Public financing and entrepreneurship: behaviour and regional heterogeneity of SMEs, Investigaciones Regionales, v. 15, p. 89-109, 2009.

TEIXEIRA, S. J.; CASTELEIRO, C. M. L.; RODRIGUES, R.; GUERRA, M. Entrepreneurial intentions and entrepreneurship in European countries, International Journal of Innovation Science, v. 10, n. 1, p. 22-42, 2018.

TRIPOPSAKUL, S. Entrepreneurial perceptions and intentions: the comparative study between Poland and Thailand, Polish Journal of Management Studies, v. 17, n. 1, p. 249-259, 2018.

VLIAMOS, S. J. Entrepreneurship and innovation at work and schools: the Greek paradigm, Entrepreneurship and Innovation Management, v. 8, n. 6, p. 686-700, 2008.

VLIAMOS, S. J.; TZEREMES, N. G. Factors influencing entrepreneurial process and firm start-ups: evidence from central Greece, Journal of the Knowledge Economy, v. 3, n. 3, p. 250-264, 2012. 
APPENDIXES

Appendix A - Adapted database from GEM (2017)

\begin{tabular}{|c|c|c|c|c|c|c|c|c|c|c|c|c|c|c|}
\hline & EI & $\mathrm{PO}$ & $\mathrm{PC}$ & MOTIV & EGCC & HSSE & TEA & EEA & HJCE & INNOV & GSP & GP & FIN & BS \\
\hline Argentina & 13.36 & 29.65 & 43.08 & 2.46 & 60.4 & 47.43 & 5.97 & 0.58 & 12.68 & 13.98 & 3.75 & 3.17 & 2.02 & 1.62 \\
\hline Australia & 13.19 & 51.39 & 49.3 & 3.75 & 53.87 & 68.91 & 12.21 & 7.81 & 28.16 & 28.51 & 2.32 & 2.61 & 2.63 & 1.88 \\
\hline Bosnia and Herzegovina & 4.55 & 13.42 & 35.49 & 1.18 & 62.66 & 65.64 & 3.95 & 0.53 & 1.73 & 10.93 & 2.07 & 2.58 & 2.34 & 2.1 \\
\hline Bulgaria & 5.01 & 19.46 & 38.36 & 1.06 & 54.29 & 67.98 & 3.7 & 0.5 & 9.38 & 13.39 & 1.86 & 2.23 & 2.62 & 1.9 \\
\hline Canada & 14.13 & 60.23 & 55.59 & 3.14 & 65.61 & 73.96 & 18.75 & 8.16 & 20.32 & 43.18 & 3.05 & 3.24 & 3.1 & 2.37 \\
\hline Chile & 45.78 & 55.53 & 61.83 & 2.32 & 73.76 & 62.87 & 23.8 & 4.46 & 29.78 & 54.01 & 2.49 & 3.08 & 2.18 & 1.58 \\
\hline China & 15.29 & 35.21 & 27.24 & 1 & 66.35 & 74.57 & 9.87 & 1.36 & 24.32 & 25.51 & 2.84 & 2.82 & 3.31 & 1.88 \\
\hline Colombia & 52.48 & 52.4 & 68.5 & 2.96 & 68.42 & 75.34 & 18.68 & 1.76 & 37.67 & 14.87 & 2.36 & 2.66 & 2.15 & 2.24 \\
\hline Croatia & 17.54 & 33.59 & 50.84 & 1.19 & 62.19 & 47.71 & 8.91 & 4.84 & 30.36 & 19.86 & 2.06 & 2.21 & 2.42 & 1.54 \\
\hline Cyprus & 16.66 & 51.01 & 46.35 & 1.62 & 66.2 & 61.53 & 7.33 & 1.83 & 8.03 & 40.92 & 2.5 & 2.07 & 2.03 & 1.91 \\
\hline Ecuador & 48.18 & 51.15 & 74.06 & 0.87 & 60.63 & 60.68 & 29.62 & 0.54 & 6.62 & 16.54 & 2.18 & 2.18 & 1.94 & 2.22 \\
\hline Egypt & 55.45 & 43.51 & 46.6 & 0.63 & 75.94 & 82.01 & 13.25 & 2.18 & 23.69 & 25.26 & 2.51 & 1.99 & 2.46 & 1.22 \\
\hline Estonia & 18.14 & 60.95 & 49.72 & 2.73 & 54.22 & 64.74 & 19.38 & 9.12 & 27.22 & 30.2 & 3 & 3.34 & 3.27 & 2.96 \\
\hline France & 17.62 & 34.13 & 36.31 & 2.99 & 59.06 & 74.21 & 3.92 & 3.87 & 27.86 & 48.63 & 3.4 & 3.24 & 2.81 & 1.84 \\
\hline Germany & 7.22 & 41.96 & 37.45 & 5.42 & 51.31 & 77.9 & 5.28 & 5.67 & 21.95 & 23.74 & 2.68 & 3.4 & 2.84 & 1.56 \\
\hline Greece & 7.12 & 13.74 & 43.4 & 1.83 & 63.36 & 66.49 & 4.82 & 0.88 & 9.91 & 26.42 & 1.99 & 1.93 & 1.92 & 1.75 \\
\hline Guatemala & 46.54 & 53.31 & 64.49 & 1.63 & 91.91 & 73.42 & 24.75 & 1.33 & 22.21 & 29.51 & 1.56 & 1.85 & 1.62 & 1.57 \\
\hline India & 10.33 & 44.92 & 42.05 & 0.75 & 52.96 & 56.18 & 9.28 & 0.21 & 9.52 & 25.6 & 3.22 & 2.81 & 3.05 & 2.17 \\
\hline Indonesia & 28.14 & 47.74 & 57.34 & 1.72 & 70.01 & 80.95 & 7.47 & 1.82 & 3.57 & 11.58 & 3.74 & 3.45 & 3.71 & 3.07 \\
\hline Iran & 38.76 & 33.62 & 53.35 & 1.59 & 48.28 & 79.4 & 13.32 & 1.17 & 35.01 & 16.15 & 2.23 & 1.34 & 1.74 & 1.85 \\
\hline Ireland & 11.92 & 44.5 & 42.21 & 2.5 & 53.24 & 81.88 & 8.93 & 5.5 & 26.89 & 42.73 & 2.64 & 3.43 & 2.66 & 1.91 \\
\hline Israel & 26.42 & 58.29 & 44.14 & 2.02 & 65.16 & 86.07 & 12.78 & 8.55 & 8.66 & 26.7 & 1.85 & 2.25 & 3.31 & 1.89 \\
\hline Italy & 10.25 & 28.78 & 30.39 & 2.52 & 64.17 & 73.21 & 4.28 & 2.41 & 13.96 & 28.22 & 2.48 & 2.4 & 2.22 & 1.75 \\
\hline Japan & 3.67 & 7.41 & 10.77 & 3.35 & 24.27 & 51.96 & 4.68 & 2.76 & 28.42 & 24.68 & 2.6 & 2.54 & 2.95 & 1.68 \\
\hline Kazakhstan & 46.22 & 50.42 & 64.68 & 1.78 & 59.65 & 80.11 & 11.32 & 4.08 & 25.43 & 23.54 & 3.21 & 2.58 & 2.78 & 1.95 \\
\hline Latvia & 17.32 & 36.28 & 49.03 & 2.06 & 57.49 & 58.54 & 14.15 & 4.43 & 27.49 & 28.41 & 2.77 & 2.85 & 2.98 & 2.56 \\
\hline Luxembourg & 10.98 & 54.77 & 40.86 & 4.08 & 42.98 & 69.95 & 9.05 & 8 & 18.45 & 57.13 & 3.05 & 3.48 & 2.46 & 1.89 \\
\hline Madagascar & 39.84 & 24.4 & 55.41 & 2.16 & 83.62 & 77.78 & 21.76 & 0.6 & 1.15 & 20.89 & 2.22 & 1.97 & 1.98 & 1.42 \\
\hline Malaysia & 17.61 & 45.06 & 46.12 & 9.22 & 77.06 & 69.88 & 21.6 & 1.4 & 13.18 & 29.33 & 2.74 & 2.68 & 3.48 & 2.14 \\
\hline Mexico & 13.2 & 36.38 & 50.07 & 2.14 & 50.67 & 52.34 & 14.14 & 1 & 10.77 & 31.71 & 3.18 & 3.2 & 2.6 & 1.59 \\
\hline Morocco & 26.64 & 37.7 & 49.64 & 1.58 & 75.81 & 63.26 & 8.76 & 0.53 & 10.8 & 18.68 & 2.17 & 2.09 & 2.02 & 1.36 \\
\hline Netherlands & 8.11 & 64.09 & 44.61 & 10.04 & 81 & 67.5 & 9.92 & 7.61 & 15.58 & 22.52 & 3.26 & 3.63 & 3.65 & 3.4 \\
\hline Panama & 20.8 & 48.86 & 57.59 & 3.17 & 60.16 & 67.46 & 16.18 & 0.15 & 17.93 & 8.51 & 2.1 & 2.69 & 1.92 & 1.58 \\
\hline Peru & 43.21 & 55.77 & 67.55 & 3.74 & 64.72 & 62.86 & 24.6 & 0.85 & 19.13 & 17.8 & 2.63 & 2.75 & 2.16 & 2.19 \\
\hline Poland & 9.69 & 68.83 & 52.36 & 7.52 & 79.26 & 67.73 & 8.85 & 3.2 & 14.89 & 12.08 & 2.7 & 2.42 & 3.03 & 1.49 \\
\hline Puerto Rico & 18.3 & 27.97 & 46.65 & 1.34 & 22.56 & 52.3 & 10.63 & 2.55 & 22.88 & 25.17 & 2.31 & 1.91 & 2.15 & 1.43 \\
\hline Qatar & 15.69 & 45.59 & 41.07 & 3.94 & 65.93 & 77.32 & 7.43 & 2.5 & 45.02 & 37.94 & 3.43 & 3.24 & 2.64 & 2.61 \\
\hline Saudi Arabia & 30.85 & 79.47 & 71.82 & 1.15 & 69.66 & 69.25 & 11.45 & 2.39 & 19.76 & 27.6 & 2.35 & 2.29 & 2.34 & 1.41 \\
\hline Slovakia & 9.04 & 25.82 & 48.45 & 1.37 & 47.55 & 59.99 & 11.8 & 2.6 & 22.88 & 29.24 & 1.94 & 1.99 & 2.9 & 1.96 \\
\hline Slovenia & 14.23 & 34.6 & 53.31 & 2.47 & 55.12 & 73.42 & 6.85 & 5.96 & 21.09 & 34.24 & 2.55 & 2.66 & 2.68 & 2.08 \\
\hline South Africa & 11.72 & 43.17 & 39.93 & 1.46 & 69.36 & 74.86 & 10.96 & 0.45 & 32 & 29.66 & 2.45 & 2.02 & 2.51 & 1.78 \\
\hline South Korea & 22.79 & 35.3 & 45.68 & 2.93 & 47.24 & 68.57 & 12.98 & 1.91 & 9.66 & 26.35 & 3.46 & 2.93 & 2.38 & 1.76 \\
\hline Spain & 5.55 & 31.86 & 44.8 & 1.7 & 53.83 & 47.88 & 6.19 & 1.35 & 8.6 & 25.01 & 2.28 & 2.95 & 2.52 & 1.82 \\
\hline Sweden & 8.08 & 79.49 & 34.5 & 5.95 & 53.6 & 70.52 & 7.29 & 6.2 & 6.34 & 29.05 & 2.23 & 2.63 & 2.88 & 2.4 \\
\hline Switzerland & 10.47 & 47.16 & 42.09 & 4.86 & 53.02 & 73.2 & 8.47 & 4.76 & 33.2 & 24.93 & 2.9 & 3.34 & 3.09 & 2.21 \\
\hline Taiwan & 25.74 & 26.57 & 25.89 & 3.67 & 71.08 & 60.13 & 8.56 & 8.08 & 42.99 & 20.19 & 2.48 & 3.01 & 2.78 & 2.4 \\
\hline Thailand & 37.36 & 49.13 & 48.86 & 7.9 & 74.72 & 74.48 & 21.62 & 4.49 & 29.56 & 29.29 & 2.75 & 2.29 & 3 & 2.03 \\
\hline United Arab Emirates & 56.33 & 35.45 & 64.79 & 3.37 & 82.73 & 87.77 & 8.97 & 1.68 & 26.63 & 18.67 & 3.74 & 3.23 & 2.96 & 3.03 \\
\hline United Kingdom & 7.27 & 42.98 & 48.21 & 4.47 & 55.59 & 75.6 & 8.4 & 7.98 & 23.39 & 27.06 & 2.61 & 2.65 & 2.74 & 1.9 \\
\hline United States & 14.54 & 63.59 & 54.31 & 7.21 & 63.05 & 75.49 & 13.64 & 7.59 & 38.61 & 35.93 & 3.02 & 2.61 & 2.97 & 2.01 \\
\hline Uruguay & 27.38 & 36.86 & 57.52 & 2.28 & 54.86 & 51.94 & 14.74 & 3.47 & 20.62 & 26.25 & 2.31 & 3.18 & 2.15 & 1.37 \\
\hline Vietnam & 24.96 & 46.41 & 53.03 & 4.6 & 62.11 & 74.77 & 23.27 & 0.6 & 9.07 & 13.86 & 1.9 & 2.09 & 2.27 & 1.83 \\
\hline
\end{tabular}


Appendix B - Description of Variables

\begin{tabular}{|c|c|}
\hline Variables & Description \\
\hline \multicolumn{2}{|l|}{ Dependent Variable } \\
\hline Entrepreneurial intentions & $\begin{array}{l}\text { Percentage of 18-64 population (individuals involved in any stage of entrepreneurial } \\
\text { activity excluded) who are latent entrepreneurs and who intend to start a business within } \\
\text { three years. }\end{array}$ \\
\hline \multicolumn{2}{|l|}{ Independent Variables } \\
\hline Perceived opportunities & $\begin{array}{l}\text { Percentage of } 18-64 \text { population who see good opportunities to start a firm in the area } \\
\text { where they live. }\end{array}$ \\
\hline Perceived capabilities & $\begin{array}{l}\text { Percentage of } 18-64 \text { population who believe they have the required skills and knowledge } \\
\text { to start a business. }\end{array}$ \\
\hline Motivational Index & $\begin{array}{l}\text { Percentage of those involved in TEA that are improvement-driven opportunity motivated, } \\
\text { divided by the percentage of TEA that is necessity-motivated. }\end{array}$ \\
\hline $\begin{array}{l}\text { Entrepreneurship as a Good Career } \\
\text { Choice }\end{array}$ & $\begin{array}{l}\text { Percentage of } 18-64 \text { population who agree with the statement that in their country, most } \\
\text { people consider starting a business as a desirable career choice. }\end{array}$ \\
\hline $\begin{array}{l}\text { High Status to Successful } \\
\text { Entrepreneurs }\end{array}$ & $\begin{array}{l}\text { Percentage of 18-64 population who agree with the statement that in their country, } \\
\text { successful entrepreneurs receive high status. }\end{array}$ \\
\hline $\begin{array}{l}\text { Total early-stage Entrepreneurial } \\
\text { Activity (TEA) }\end{array}$ & $\begin{array}{l}\text { Percentage of } 18-64 \text { population who are either a nascent entrepreneur or owner-manager } \\
\text { of a new business. }\end{array}$ \\
\hline Entrepreneurial Employee Activity & $\begin{array}{l}\text { Rate of involvement of employees in entrepreneurial activities, such as developing or } \\
\text { launching new goods or services, or setting up a new business unit, a new establishment or } \\
\text { subsidiary. }\end{array}$ \\
\hline High Job Creation Expectation & Percentage of those involved in TEA who expect to create 6 or more jobs in 5 years. \\
\hline Innovation & $\begin{array}{l}\text { Percentage of those involved in TEA who indicate that their product or service is new to } \\
\text { at least some customers AND that few/no businesses offer the same product. }\end{array}$ \\
\hline Governmental support and policies & $\begin{array}{l}\text { The extent to which public policies support entrepreneurship - entrepreneurship as a } \\
\text { relevant economic issue. }\end{array}$ \\
\hline Governmental programs & $\begin{array}{l}\text { The presence and quality of programs directly assisting SMEs at all levels of government } \\
\text { (national, regional, municipal). }\end{array}$ \\
\hline Financing for entrepreneurs & $\begin{array}{l}\text { The availability of financial resources (equity and debt) for small and medium enterprises } \\
\text { (SMEs) (including grants and subsidies). }\end{array}$ \\
\hline $\begin{array}{l}\text { Basic school entrepreneurial education } \\
\text { and training }\end{array}$ & $\begin{array}{l}\text { The extent to which training in creating or managing SMEs is incorporated within the } \\
\text { education and training system at primary and secondary levels. }\end{array}$ \\
\hline
\end{tabular}

Appendix C - Assumption of the model: Normal Distribution and Homogeneity 


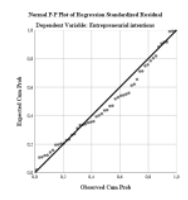

